\title{
A KISKERESKEDELEM TEREI GYŐRBEN
}

\author{
(The spheres of the retail trade in Györ)
}

\section{NAGY ERIKA}

A kilencvenes évek eleji Magyarországon a kereskedelem vonzotta a legtöbb hazai és külföldi befektetót a gazdasági szektorok közül. A szereplők száma megsokszorozódott, s ezzel párhuzamosan szervezeti átalakulás zajlott az ágazatban. Ennek fóbb jellemzői a dekoncentráció - az új kis- és középvállalatok tömeges megjelenése, illetve az állami nagyvállalatok egy részének felbomlása következményeként -, a piac feldarabolódása és új szervezeti formák megjelenése. Ez a gyors növekedési szakasz 1994-95-től kezdve átadta helyét egy stabilizálódó, és a szervezeti koncentráció jeleit mutató fejlődésnek. Utóbbi jelenség az állami vállatok átalakulása és privatizációja lezárulásával, továbbá a külfoòldi befektetók által megvalósított nagyberuházásokkal magyarázható, míg az elóbbi a vásárlóerő folyamatos csökkenésével és a piac telítődésével. A struktúra stabilizálódásának kezdetét és a koncentrácós folyamat intenzitását tekintve időbeli eltolódás mutatkozik Budapest és Északnyugat-Magyarország, illetve az ország többi része kőzőtt: elöbbi régiókban az ủj szakasz korábban kezdődőtt.

A szervezeti változások a kereskedelem körébe tartozó tevékenységek jelentős bóvülésével jártak: egyre több cég vállalt - például márkaképviseletet, $s$ a külkereskedelemi és a közvetítői tevékenységet folytató szervezetek száma is gyorsan gyarapodott. Ennek okai a liberalizációs folyamatban, illetve az ellátandó kiskereskedelmi egységek számának növekedésében keresendők. Ugyanakkor bővült az eladott termékek köre, és könnyebben elérhetövé váltak a müszaki cikkek, autók, exkluzív ruházati cikkek stb. Az elmúlt három évben a kereskedelemhez, illetve az egyes árucikkekhez kapcsoló szolgáltatások szerepe is növekedett (javítás, karbantartás, a vásárló igényeihez való igazítás stb.) s ez a tendencia várhatóan meg is marad az erős verseny és a külföldi cégek jelenléte miatt, amelyek tevékenysége mintául szolgál a hazai vállalkozók számára.

A vázolt átalakulás legfontosabb centrumai a városok, közülük is a regionális nagykereskedelmi-elosztó kőzpontok. Ezek méretei - területük, lakosságszámuk, szerepköreik összetettsége - lehetóvé teszi, hogy a kereskedelem térszerkezeti változásait, a kiskereskedelmi-szolgáltató funkciót ellátó tömörülések hierarchizáltságát és az ezekhez kapcsolódó mozgásokat a településhatáron belül is vizsgáljuk.

\section{A kiskereskedelem térszerkezeti elemei}

A klasszikus megközelítések ingatlan árak és bérleti díjak térbeli sajátosságaira koncentráltak a kiskereskedelem térszerkezetét alakító tényezök vizsgálatakor. (Alonso 1971) modellje szerint egykőzpontú térszerkezet esetén a cityben a legmagasabbak az árak - és a költségek -, ezért az itt tömörülö üzletek nagy értékü, ritka árucikkeket kínálnak. A peremek felé haladva az ingatlanárak csőkkenésével. változik a kiskereskedelmi egységek 
tevékenysége és alapterülete. Az Alonso-féle elképzelésből kiindulva és a központi hely elméletét felhasználva dolgozta ki (Berry 1967) részletes hierarchikus modelljét. Ebben a kiskereskedelmi koncentrációk négy szintjét különítette el az ơnálló, napi cikkeket árusító vegyesboltoktól a tervezett, specializált üzletekkel és szolgáltatásokkal ellátott központokig. A két szint közötti átmenetet a napi szükségleti cikkeket és szolgáltatásokat nyújtó koncentrációk, illetve az egy-egy városrész ellátását biztosító, néhány lakossági szolgáltatást nyújtó (posta, bank) és specializált üzletekkel rendelkező (pékség, édességbolt, ruházati cikkek) tömörülések képviselik. Berry ezek mellett speciális, nagy helyigényü funkcionális területeket (építőipari-lakberendezési, müszaki stb.) és a kivezetö utak mellé települt sajátos szerkezetü tömörüléseket (üzemanyag-kereskedelem, szálláshely-szolgáltatás, vendéglátás) különböztetett meg. Az ingatlanárak mellett azonban hangsúlyozta a társadalom térbeni szerkezetének fontos telepítỏ hatását: az egyes elemek helyét a potenciális kereslet alakítja, tehát a magasabb hierarchiaszintủ kiskereskedelmi központok a tehetösebbek lakónegyedeiben találhatóak meg.

A fenti modellt a későbbi kutatások kiindulópontnak tekintették, ám többnyire kritikusan írnak róla. Ennek oka, hogy számos tényezö - város-rekonstrukciók, városi ingatlanpolitika, az üzletek specializációja, a személy- és tőmegközlekedés, életmódbeli különbségek stb. - alakítja még a kereskedelem térszerkezetét. A legtöbb bírálat az európai geográfusok részéről érte a modellt, illetve annak érvényességét (Dawson 1983, Daniels 1985). Új, átfogó megközelítést a behaviorizmus adott. A kereskedelem térszerkezetét és a bevásárlóutakat az érdekelt szereplök döntései alakítják: a kereskedóké, a lakosságé és a helyi önkormányzaté (ingatlanbérleti dijakon, városrendezési akciókon, közlekedési szabályokon keresztül) (van den Berg 1987, Price - Blair 1989).

A kereskedelem térszerkezetére irányuló kutatások a nyolcvanas években kaptak új lendületet Európában. Ennek oka a "bevásárlóközpont-boom", amellyel új elem, a tervezett, komplex kereskedelmi és szolgáltató funkciókat tömörítö, többnyire a város peremén elhelyezkedö centrum jelent meg a kiskereskedelem szerkezetében. A központok kettős folyamat eredményeképpen kezdtek gyors ütemben gyarapodni. Az egyik a hatvanas, hetvenes években Nyugat- és Közép-Európában nekilendülö szuburbanizáció (van den Berg, et. al; Enyedi 1988), a másik a kereskedelmi szektorban lezajlott szervezeti koncentráció. Hatására megindult a kiskereskedelem térbeli átalakulása is, a szektor fö terjeszkedési területévé a nagyobb városok peremterületei váltak. A belváros hagyományos kiskereskedelmi szerepkörének megörzése érdekében rekonstrukciós hullám indult el, amelyet számos közép- és nagyvárosban a sétálooövezetek kiterjesztése kísért (Monheim 1991). Részben az önkormányzatok lépései, részben a belváros vonzereje (Klein 1991) a magyarázata annak, hogy törekvéseik sikeresek. A belvárosi struktúra azonban átalakult: a napi cikkeket árusító üzletek közül csak a nagy áruházak őrizték meg helyüket; a kisebb üzletek körében specializációs és szervezeti betagozódás volt megfigyelhetó valamely nagyobb vertikális szerveződésbe.

Az európai nagy- és középvárosok ( 100 ezernél népesebb települések) kereskedelmében tehát a szervezeti koncentrációt térbeli dekoncentráció kísérte, elsősorban a szuburbán peremterületek javára és a belváros rovására. Ugyanakkor a belső, sürü beépítésú lakóterületeken a kisebb, 50-100 négyzetméteres, szubcentrumok közelében fekvő vegyesboltok szerepe továbbra is fontos, kuloonösen hosszú nyitvatartásuk miatt (Price, Blair, et. al.). Az ingatlan árak emelkedése az üzletek raktározási lehetỏségeit is szúkíti a szuburbán övezeten belül, ezért a városközpontba vezetô utak mellett jelentősen növekedtek a raktározási területek. 
Tér és Társadalom 10. évf. 1996/2-3. 141-147. p.

\section{A győri kereskedelem szerkezeti változásai}

A szervezeti változások elsô szakasza a nyolcvanas évek elején, a szerződéses üzletek, majd a bérletek elterjedésével kezdődött. Az ủj üzemeltetési formák elsősorban a gyengébben ellátott hagyományos beépítésü lakóövben és a peremterületeken terjedtek el, és többnyire élelmiszer-, vagy vegyesboltok voltak. A magánszektor másik fontos elemét a kis alapterületủ, ám jó minőségủ árut kínáló belvárosi üzletek jelentették, amelyek ruházati cikkeket és kiegészítóket forgalmaztak. Ezek már ekkor komoly versenyt jelentettek a nagyobb áruházak számára.

A szervezeti változások 1989-től kezdve felgyorsultak. Mivel ebben a szektorban alapították a legtöbb társaságot és magánvállalkozást, Győrben is jellemző volt az elaprózódás és a döntések dekoncentrációja. A gründolás 1991-92-ben érte el a tetőpontját, azóta folyamatosan mérséklődik az alapítások üteme. A folyamat eredménye közel hatszáz jogi személyiségú és csaknem ugyanennyi jogi személyiség nélküli társas vállalkozás. A gyors növekedés hátterében a kereskedelem jövedelmezősége mellett a város fekvése és közlekedési kapcsolatai és az ennek köszönhető kedvező értékesítési lehetőségek, továbbá a helyi kereslet játszott fontos szerepet a vállalkozók véleménye szerint. Fontos tényezőnek bizonyult a nagyobb (százmillió forintnál nagyobb éves forgalmat bonyolító) szervezetek esetében a kereskedelmi tapasztalat és a már kialakult üzleti kapcsolatok, amelyeket állami vállalatoknál, vagy a nyolcvanas években magánvállalkozóként alakítottak ki. A szerény méretú, egy-egy üzletet múködtető családi vállalkozásoknál - különösen a napi cikkekkel kereskedők között - viszont gyakori motiváció a munkanélkủliség.

Ezzel párhuzamosan megkezdődött az állami vállalatok átalakulása és privatizációja. A folyamatban, amely a kilencvenes évek közepén lényegében lezárult, a hazai magántöke elsősorban a vállalati vezetők - és a külföldi befektetők játszottak fontos szerepet. A feldarabolódó piacon a hagyományos szereplök tevékenységük átalakításával próbálnak versenyképesek maradni: a nagykereskedelemben ez az áruszerkezet bóvítését, a kiskereskedelemben specializációt, illetve helyi, vagy regionális üzletlánc kiépítését jelenti. A nagykereskedelmi cégekkel való együttmúködés, felvásárlási szövetségekben való részvétel is előfordul. A korábban csak elosztó funkciót ellátó vállalatok is igyekeznek közvetlen kapcsolatokat kiépíteni a fogyasztókkal. Tehát a nagy- és kiskereskedelemi tevékenység keveredése figyelhető meg, amely szervezeti koncentráció felé is mutat.

A kereskedelmi tevékenység árucsoportok szerint meglehetősen vegyes képet mutat. A legnépszerúbb a napi cikkek (élelmiszer, háztartartási vegyiáruk), illetve a ruházati termékek és kiegészítőik forgalmazása. A legutóbbi évekig ezért piacuk erősen szabdalt volt, és a szakmabeliek megítélése szerint az új üzletek nagy része müködtetésének szakmai színvonala erősen kifogásolható volt. Az 1994-95-ben megnyitott ủj élelmiszeráruházak, amelyek nemzetkőzi láncok, vagy helyi vertikális szervezỏdések elemei, pozitívan befolyásolták a szakmai minőséget. A mủszaki cikkek, jármüvek és építỏiparilakásfelszerelési szakủzletek, áruházak jelentős nagyobb részét szintén az átalakulás időszakában nyitották. Ezeket igen pozitívan ítélték meg a kereskedők, az áruk megbízható minősége és háttérszolgáltatásaik miatt.

Egészében véve tehát 1994-ig a szétaprózottság, a szervezeti változások, a tőkeberuházások alacsony szintje és a meglehetősen ellentmondásos szakmai szinvonal 
jellemezte a győri kereskedelemi szektort. Az elmúlt másfél-két évben azonban megnövekedett a beruházások mértéke, amelyeket túlnyomórészt tőkeerős, hálózatokat üzemeltető szervezetek hajtottak végre. Emelkedni kezdett az ágazatban foglalkoztatottak száma is. Ugyanakkor a kisvállalkozások körébe növekedett a csődök száma, és minimálisra csökkent az alapitásoké. A koncentráció tendenciák tehát erösödtek, ami várhatóan a szereplök számának további csökkenésével jár majd.

\section{A kereskedelem térszerkezetének jellemzöi}

Az üzletek száma négy-ötszörösére emelkedett 1993 végéig a városban, azóta némi csökkenés tapasztalható. A kereskedelmi tevékenység - a szervezetek és az üzletek térbeli dekoncentrációjával járt együtt a folyamat. A vállalkozások döntéshozatali központjai elválhatnak a tényleges tevékenységtöl, ami egyrészt a jelentős forgalmat bonyolító, általában üzlethálózatot müködtető szervezetek esetében jellemzö (ekkor a központ az üzlet, vagy a raktárbázis mellett található), másrészt a nagykereskedelemben érdekelt cégeknél, amelyek központjai erösen szóródnak (a belváros mellett a nagyobb presztízsủ lakótelep, Marcalváros, a cityhez közeli Nádorváros és a déli peremterület családi házas övezete, tovább Gyárváros a jelentősebb koncentrációk). (1.ábra)

A kiskereskedelemben jóval gyakoribb az üzlet és a központ egybeesése. Ennek legfontosabb tömörülése a belvárosban található, ami erösen zsúfolttá tette annak középső részét, a bevásárló utca környékét. Jelentős koncentrációk találhatóak még a cityhez közeli városrészekben és a forgalmas, kőzpontba vezetö utak mentén. A régebben épült lakótelepek és a távol esö csatolt települések érezték legkevésbé a dekoncentráció hatásait.

$\mathrm{Az}$ üzletek térbeli elhelyezkedése, azok térbeli hierarchiája, amely az áruk és a vásárlók áramlását meghatározza, csak empirikus úton vizsgálható megfelelö kataszter híján. Ezért a városban található jelentösebb tömörülések számbavétele és ezek szerkezeti jegyeinek meghatározása teszi lehetővé átfogó kép kialakítását a térszerkezetről.

A térszerkezet legfontosabb, központi eleme továbbra is a belvárosi tömörülés, ahol az erősen tagolt városszerkezet miatt különösen fontos a jelenlét a kereskedök számára. (A koncentráció vonzását erősíti a tömegkőzlekedés rendkívül erös belvárosi orientációja is.) Az itt található üzletek szinte kivétel nélkül erősen specializálódtak az eladott áruk körét és gyakran (az esetek kb. harmadánál) egy-egy társadalmi csoport igényeit tekintve is. A bevásárló utca üzleteinek kétharmadát nyitották meg 1989 óta, $\mathrm{s}$ ez azok felújításával is együtt járt. Itt találhatóak meg a nálunk még újnak számító szervezödési formák (pl. franchise) egységei is legnagyobb számban. Az eladott áruk többsége (mintegy 40\%-a) a ruházati cikkek és kiegészitő̉k körébe tartozik. Az üzletek mérete változatos: 10-tôl 4000 négyzetméterig terjed, $\mathrm{s}$ hasonló mértékủ szóródást tapasztalunk a forgalom nagyságát tekintve is.

A fentihez hasonló változatosság és koncentráció nem található meg máshol a városban. A térbeli hierarchia formálódására utalnak azonban a napi cikkeket és szolgáltatásokat nyújtó, térben többé-kevésbé összefüggő tömörülések, amelyek néhány föbb kőzlekedési útvonal mentén, elsősorban a lakótelepeken alakultak ki, busszal legalább 15 percnyi távolságra a belvárostól. Az itteni üzletek föbb telepító tényezöi a magas népsürủség (koncentrált kereslet); az elérhetöség; valamilyen, már korábban is létező intézmény (pl. vásárcsarnok, posta) közelsége; buszmegálló, $\mathrm{ABC}$-áruház szomszédsága. 
Tér és Társadalom 10. évf. 1996/2-3. 141-147. p.

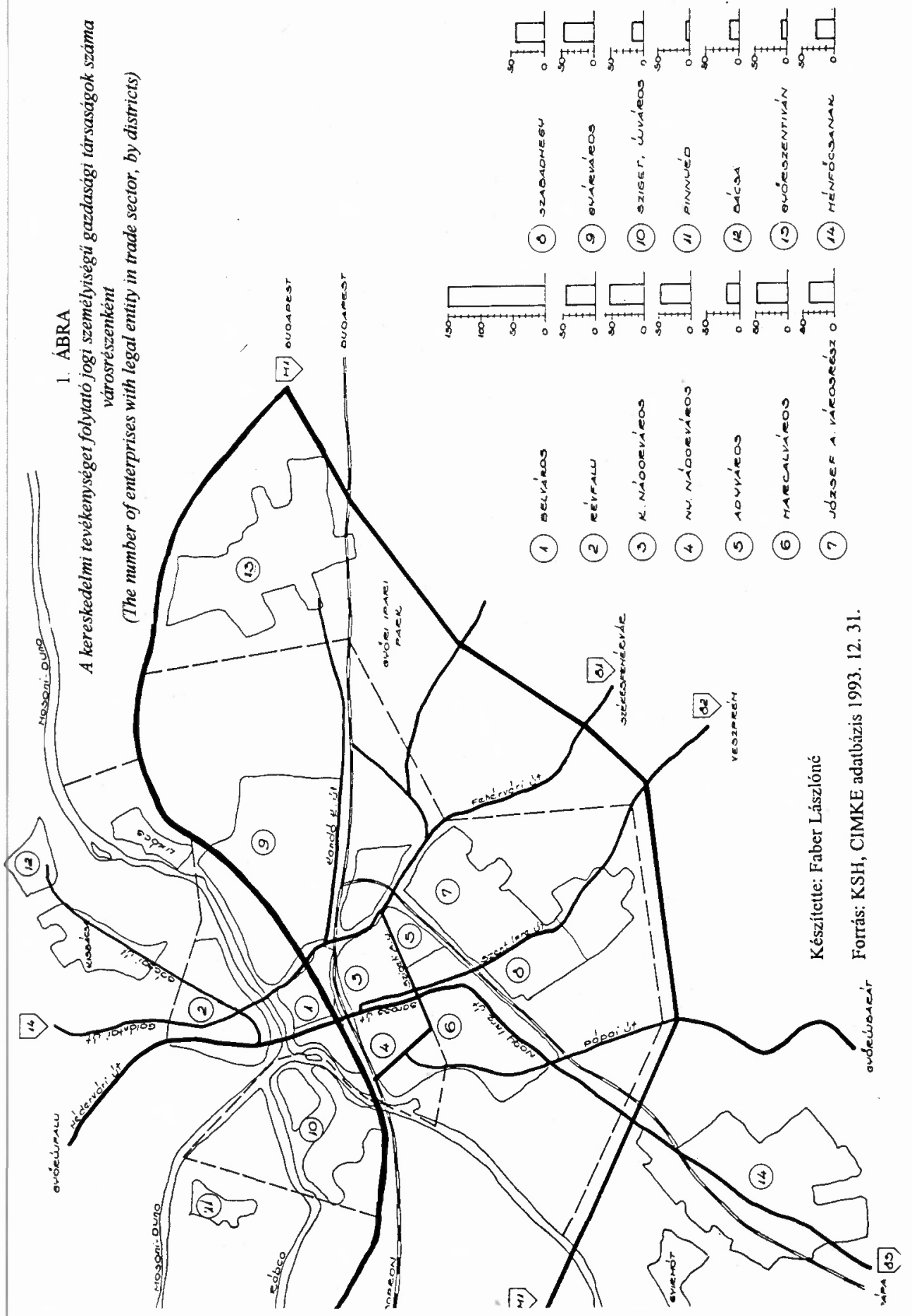


Ezek körül egy-egy útvonal mentén több kis tömörülés is kialakulhat. Elhelyezkedésük tengelyszerú, nem húzódnak a lakóterület belsejébe. Az itt található üzletek a napi kisebb bevásárlások színhelyei. A legfontosabb csoport az élelmiszerüzleteké, de jelen vannak a kisebb drogériák, virágüzletek, szerényebb kínálattal és minőséggel a ruházati cikkek (használt ruha); a szolgáltatások közül a fodrászat, kozmetika, videofilm-kölcsönzés. A vendéglátóipar büfék, apró cukrászdák és kocsmák formájában van jelen.

A jelentősebb koncentrációkban felbukkannak a szolgáltató tevékenységek magasabb szintjét képviselő fotó- és optikai szolgáltatások, kerékpárjavítás, az üzletek közül a játékés ajándék, jármüalkatrész, könyv- és ruházati boltok. Ezek a jelentősebb útkereszteződésekben bukkannak fel a városrendezési tervek nyomán kialakitott intézményi-kiskereskedelmi szubcentrumok közelében (Marcalvárosban, illetve Adyváros és Nádorváros határán). Közülük kettőt - a két legnagyobb lakótelepen kialakult koncentrációkat - sorolhatunk a kereskedelem térbeli hierarchiája magasabb szintjéhez. Ezek fent említett, specializált üzletei mellett a hétvégi bevásárlóutak célpontjai: a városi vásárcsarnok, illetve a diszkont áruházak vonzanak nagyobb számú vásárlót.

A térszerkezet fontos elemei a Berry által is említett nagy alapterületű üzletekböl álló speciális funkcionális területek az ipari városrészben és a város peremén, a kivezető forgalmas utak külsỏ szakaszán; továbbá az ezek töszomszédságában formálódó, az autósok igényeit kielégítő szolgáltató-kereskedelmi tömörülések.

A dekoncentrációs folyamat mellett tehát koncentráció is zajlott a györi kereskedelemben. Ennek köszönhetően a napi bevásárlóutak hossza csökkent, és javult a napi, heti gyakorisággal igénybe vett szolgáltatások elérhetösége is. A lakóövezetekben megjelent új üzletek azonban nem csökkentették jelentösen a belváros vonzerejét; az itt megindult specializáció, a tömegközlekedés szerepe inkább fölértékelték a városrészt a kereskedők és a vásárlók számára. Az 1995-ben megnyitott ủj, nagy alapterületủ bevásárló központok és élelmiszer áruházak elsősorban a kisebb élelmiszerboltok forgalmát csökkenthetik. Elhelyezkedésük pedig a már kialakult kiskereskedelmi szubcentrumok vonzerejét növeli.

\section{Irodalom}

Alonso, W, (1971) A Theory of the Urban Land Market. In: Internal Structure of the City (ed: Bourne, L.S.), Oxford University Press, London-New York. 154-160. o.

Berg, L, Van Den, (1987) Urban System in a Dynamic Society. Gower, Brookfield, Vermont. 119. o.

Berry, B.J.L, (1967) Geography of Market Centres and Retail Distribution. Engelwood Cliffs

Daniels, P.W, (1985) Service Industries: A Geographical Appraisal. Methuen. London, 269. 0.

Dawson, J. A, (1982) Commercial Distribution in Europe. Croom Helm, London. 232. o.

Eenyedi Gy, (1988) A városnövekedés szakaszai. Akadémiai Kiadó, Budapest, 116. o.

Hansen W. G. (1959) How Accessibility Shapes Land Use. Journal os the American Institute of Planners, May 245-262. o.

Price, D.G, Blair, A.M, (1989) The Changing Geography of the Service Sector. Belhaven Press, London 280.0. 


\section{Abstract}

In the early $90^{\prime}$-es the trade was the most attractive economic sector for the investors in Hungary or the foreigners. The number of actors were multiplied, and paralell with this process there was a constitutional change, too.

The most important centres of this transformation were the big cities, especially the wholesale trade division centres. In these cities with their population, area, and special functions can give us a chance to analyse the changes of the trade sector, e.g. the spatial structure, the hierarchy of the retail trade and service centres, and the movements inside the city.

This spatial structure and this hierarchy can be analysed only an empiric way, because the detailed business and property catasteres are missing. So, if we are able to collect the most important and the smaller clusters, and we can specify the structural characters of them, we have a chance to form a real picture of the inner structure of the city. 